University of Nebraska - Lincoln

DigitalCommons@University of Nebraska - Lincoln

Agronomy \& Horticulture - Faculty Publications

Agronomy and Horticulture Department

1972

\title{
Oxidation of Phenylpyruvate by Sweetclover Peroxidase
}

T. A. Jaynes

University of Nebraska-Lincoln

Francis A. Haskins

University of Nebraska-Lincoln, fhaskins@neb.rr.com

H. J. Gorz

University of Nebraska-Lincoln

Follow this and additional works at: https://digitalcommons.unl.edu/agronomyfacpub

Part of the Plant Sciences Commons

Jaynes, T. A.; Haskins, Francis A.; and Gorz, H. J., "Oxidation of Phenylpyruvate by Sweetclover Peroxidase" (1972). Agronomy \& Horticulture -- Faculty Publications. 175.

https://digitalcommons.unl.edu/agronomyfacpub/175

This Article is brought to you for free and open access by the Agronomy and Horticulture Department at DigitalCommons@University of Nebraska - Lincoln. It has been accepted for inclusion in Agronomy \& Horticulture -Faculty Publications by an authorized administrator of DigitalCommons@University of Nebraska - Lincoln. 


\title{
OXIDATION OF PHENYLPYRUVATE BY SWEETCLOVER PEROXIDASE*
}

\author{
T. A. JAYNeS, F. A. HASkins and H. J. GorZ \\ Department of Agronomy, University of Nebraska, Lincoln, Nebraska, U.S.A.
}

(Received 6 May 1971, in revised form 15 June 1971)

\begin{abstract}
Sweetclover (Melilotus alba Desr.) contains a soluble enzyme which oxidizes phenylpyruvate with the addition of either a natural cofactor or $\mathrm{Mn}^{2+}$ and dichlorophenol. The final product of oxidation has not been identified. Phenylpyruvate oxidation is catalyzed also by horseradish peroxidase, and the oxidation is enhanced by the natural cofactor from sweetclover or $\mathrm{Mn}^{2+}$ and dichlorophenol. After fractionation of sweetclover homogenates by DEAE-cellulose chromatography, two peaks of peroxidase activity (pyrogallol as substrate) are apparent; both peaks also oxidize phenylpyruvate. A third peak, specific for phenylpyruvate oxidation, also is apparent. The $C u / c u$ and $B / b$ allelic pairs, which influence phenolic metabolism in sweetclover have little, if any, influence on peroxidase activity. An autoxidation of phenylpyruvate occurs at high $\mathrm{Mn}^{2+}$ concentrations.
\end{abstract}

\section{INTRODUCTION}

THE FUNCTION of peroxidase in plant cells is uncertain. It has been implicated in indoleacetic acid (IAA) destruction ${ }^{1}$ as well as in the synthesis of lignin. ${ }^{2}$ The enzyme reacts anaerobically with some substrates, e.g. guaiacol and pyrogallol, with $\mathrm{H}_{2} \mathrm{O}_{2}$ as an electron acceptor. Also, it will oxidize IAA upon addition of cofactors, e.g. $\mathrm{Mn}^{2+}$ and 2,4-dichlorophenol (DCP), in place of $\mathrm{H}_{2} \mathrm{O}_{2}$. Several natural cofactors for the oxidative reaction have been identified. ${ }^{3,4}$ Buhler and Mason ${ }^{5}$ described the non-specific hydroxylation of cinnamic acid in the presence of horseradish peroxidase and dihydroxyfumarate. Their observation leads to the suggestion that in sweetclover (Melilotus alba Desr.), peroxidase may be responsible for the formation of $o$-hydroxycinnamic acid $(o-\mathrm{HCA})$ from cinnamic acid. Sweetclover contains relatively large quantities of the glucosides of cis- and trans-o-HCA, ${ }^{6}$ but attempts to detect a specific cinnamic acid $o$-hydroxylase in plant extracts have been unsuccessful. ${ }^{7}$

In this paper the enzymatic oxidation of phenylpyruvate, apparently by sweetclover peroxidase, is described. Conn and $\mathrm{Seki}^{8}$ reported that an enzyme in lupine mitochondria oxidizes phenylpyruvate to benzaldehyde and $\mathrm{CO}_{2}$. However, benzaldehyde was not detected as a product of sweetclover preparations used in this study.

* Cooperative investigations of the Plant Science Research Division, Agricultural Research Service, U.S. Department of Agriculture, and the Nebraska Agricultural Experiment Station. Supported in part by the National Science Foundation (Grant No. GB-8280). Published with the approval of the Director as Paper No. 3027, Journal Series, Nebraska Agricultural Experiment Station.

1 P. M. RAY, Arch. Biochem. Biophys. 96, 199 (1962).

${ }^{2}$ H. A. StafFord, Plant Physiol. 39, 350 (1964).

${ }^{3}$ F. E. Mumford, H. M. STARK and D. H. SMith, Phytochem. 2, 215 (1963).

${ }^{4}$ H. Sharpensteen and A. W. Galston, Physiol. Plantarum 12, 465 (1959).

${ }^{5}$ D. R. Buhler and H. S. MAson, Arch. Biochem. Biophys. 92, 424 (1961).

${ }^{6}$ W. R. Akeson, H. J. Gorz and F. A. Haskins, Crop Sci. 3, 167 (1963).

7 E. E. Conn, in Biochemistry of Phenolic Compounds (edited by J. B. HARBorne), p. 399. Academic Press, New York (1964).

${ }^{8}$ E. E. ConN and S. L. Sekr, Fed. Proceed. 16, 197 (1957). 


\section{RESULTS}

Initially a disappearance of phenylpyruvate was noted upon incubation with whole sweetclover seedlings. The incubation mixture was chromatographed on paper followed by detection of phenylpyruvate with diazotized $p$-nitroaniline. ${ }^{9}$ No product of the reaction was detected.

Phenylpyruvate was lost as well upon incubation with homogenates of sweetclover seedlings or young vegetative tissue. When such homogenates were passed through a column of Sephadex G-25, no enzyme activity was detected in the column effluent. However, activity could be recovered upon addition of a boiled, nondeionized homogenate which apparently contained a natural cofactor (Table 1). The boiled extract alone caused little loss

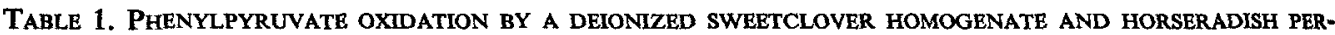
OXIDASE USING ETTHER THE NATURAL COFACTOR OR $\mathrm{Mn}^{2+}$ AND DCP

\begin{tabular}{|c|c|c|c|c|c|c|c|}
\hline & & & H assay & & & PH assay & \\
\hline & & Inc & $\begin{array}{l}\text { ion time } \\
\text { in) }\end{array}$ & & Inc & $\begin{array}{l}\text { ion time } \\
\text { in) }\end{array}$ & \\
\hline Natural & $\mathrm{Mn}^{2+}+\mathrm{DCP}$ & 0 & 30 & $30 / 0$ & 0 & 30 & $30 / 0$ \\
\hline Sweetclo & nate & & & & & & \\
\hline $\overrightarrow{+}$ & $\overline{-}$ & $\begin{array}{l}1 \cdot 160 \\
1 \cdot 200 \\
1 \cdot 178\end{array}$ & $\begin{array}{l}1 \cdot 150 \\
1.097 \\
0.950\end{array}$ & $\begin{array}{l}0.99 \\
0.91 \\
0.81\end{array}$ & $\begin{array}{l}0.441 \\
0.466 \\
0.478\end{array}$ & $\begin{array}{l}0.441 \\
0.432 \\
0 \cdot 371\end{array}$ & $\begin{array}{l}1.00 \\
0.93 \\
0.78\end{array}$ \\
\hline Horserad & lase & & & & & & \\
\hline$\frac{-}{+}$ & $\begin{array}{l}- \\
+\end{array}$ & $\begin{array}{l}1.198 \\
1.223 \\
1.200\end{array}$ & $\begin{array}{l}1 \cdot 105 \\
1.030 \\
0 \cdot 881\end{array}$ & $\begin{array}{l}0.92 \\
0.84 \\
0.73\end{array}$ & $\begin{array}{l}0.445 \\
0.425 \\
0.435\end{array}$ & $\begin{array}{l}0 \cdot 405 \\
0 \cdot 371 \\
0 \cdot 320\end{array}$ & $\begin{array}{l}0.91 \\
0.87 \\
0.74\end{array}$ \\
\hline
\end{tabular}

* Absorbance of reaction mixture at $320 \mathrm{~nm}$ after addition of $\mathrm{NaOH}$.

$\dagger$ Absorbance at $380 \mathrm{~nm}$ of 2,4-dinitrophenylhydrazones in $\mathrm{Na}_{2} \mathrm{CO}_{3}$ solution.

of phenylpyruvate. Cofactor activity was detected only in fresh shoot homogenates which had been allowed to stand at $5^{\circ}$ overnight before boiling, or in boiled homogenates prepared from frozen shoots. The cofactor present in the boiled homogenate was not extracted with ether at any $\mathrm{pH}$, nor was it recovered after fractionation of the homogenate on a Sephadex G-25 column. Low concentrations of $\mathrm{Mn}^{2+}$ and DCP effectively replaced the natural cofactor (Table 1). Additionally oxygen was required for activity. If the reaction volume was increased to $5 \mathrm{ml}$ (from $0.2 \mathrm{ml}$ ), little phenylpyruvate was lost unless the mixture was aerated. The borate buffer used in the reaction mixture is known to complex with phenylpyruvate, ${ }^{10}$ but this buffer was not essential for the reaction. The enzyme was most active at $\mathrm{pH} 8 \cdot 5$.

Phenylpyruvate disappearance was followed by adding $\mathrm{NaOH}$ to the reaction mixture and measuring absorbance at $320 \mathrm{~nm}$, the approximate absorption maximum of this compound in base. With the decrease in absorbance at $320 \mathrm{~nm}$, a new maximum appeared at $250 \mathrm{~nm}$ (Fig. 1). This new peak was detected in acid or neutral solutions of the reaction

9 O. L. Gamborg, L. R. Welter and A. C. Neish, Phytochem. 1, 159 (1962).

10 W. E. Knox and B. M. Pitt, J. Biol. Chem. 225, 675 (1957). 


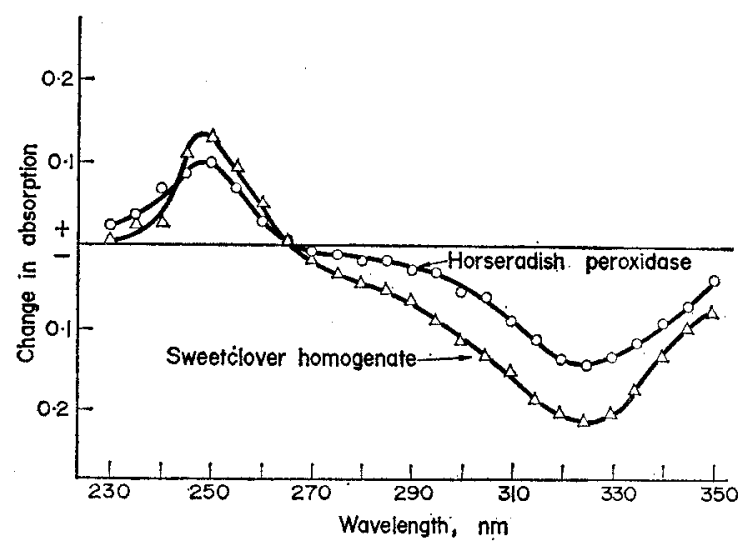

Fig. 1. Change in ABSORPTION SPECTRUM OF REACTION MIXTURE EFFECTED BY 30 min INCUBATION WITH SWEETCLOVER HOMOGENATE AND HORSERADISH PEROXIDASE.

mixture as well as in base. However, the relationship between the loss at $320 \mathrm{~nm}$ and the increase at $250 \mathrm{~nm}$ did not remain constant with increasing time of reaction. Possibly the $250 \mathrm{~nm}$-absorbing substance was an unstable intermediate of phenylpyruvate oxidation. Attempts to extract the substance into ether from acidic, basic, or neutral solutions were unsuccessful, as were attempts to recover it from a Sephadex G-25 column. Benzaldehyde has an absorption maximum near $250 \mathrm{~nm}$, but unlike the $250 \mathrm{~nm}$-absorbing substance encountered here, benzaldehyde was readily extracted into ether from an acidic solution. The possibility that benzaldehyde may have been converted rapidly to other products, thereby escaping detection, was discounted by the observation that no apparent loss of benzaldehyde added to the reaction mixture occurred.

Phenylpyruvate also was measured with the carbonyl reagent, 2,4-dinitrophenylhydrazine (DNPH). As shown in Table 1, both methods of assay indicated similar losses of phenylpyruvate. This was true with either the natural cofactor or $\mathrm{Mn}^{2+}$ and DCP. Upon reaction with DNPH, successive samples of a phenylpyruvate oxidation mixture displayed a visible decrease in quantity of insoluble 2,4-dinitrophenylhydrazones. This decrease paralleled the loss indicated by the colorimetric assay of 2,4-dinitrophenylhydrazones following ether and $\mathrm{Na}_{2} \mathrm{CO}_{3}$ extraction. It is noteworthy that reaction of benzaldehyde with DNPH produced an insoluble 2,4-dinitrophenylhydrazone. Thus, if benzaldehyde were a principal product of phenylpyruvate oxidation, the aforementioned decrease in quantity of insoluble 2,4-dinitrophenylhydrazones probably would not have occurred. The product formed by reacting benzaldehyde with DNPH was soluble in ether, but it remained in the ether phase during extraction with $\mathrm{Na}_{2} \mathrm{CO}_{3}$ solution. Therefore, this product, if present, would not have interfered with the colorimetric assay of phenylpyruvate.

$\mathrm{Mn}^{2+}$ and DCP, which serve as cofactors for phenylpyruvate oxidation, also are used in peroxidase systems. ${ }^{1,4.11}$ Accordingly horseradish peroxidase was tested for its ability to oxidize phenylpyruvate. Like the sweetclover enzyme, horseradish peroxidase effected an increase in absorbance at $250 \mathrm{~nm}$ and a decrease at $320 \mathrm{~nm}$ (Fig. 1). The horseradish peroxidase also oxidized phenylpyruvate with the natural cofactor from sweetclover (Table 1).

11 B. Z. Siegel and A. W. Galston, Science 157, 1557 (1967). 
Nonenzymatic loss of phenylpyruvate was first observed in an experiment concerning optimal levels of the cofactors. At the concentration used in typical incubations with enzyme preparations, $\mathrm{Mn}^{2+}$ produced little loss of phenylpyruvate, but a 10 -fold increase in that concentration resulted in appreciable nonenzymatic loss (Table 2). This loss was indicated

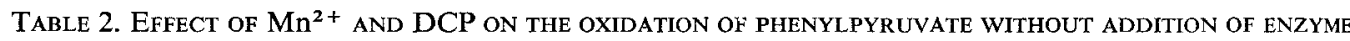

\begin{tabular}{|c|c|c|c|c|c|c|c|}
\hline & & & $\mathrm{H}$ assay & & & H assay & \\
\hline & & & $\begin{array}{l}\text { ion time } \\
\text { n) }\end{array}$ & & Inc & $\begin{array}{l}\text { ion time } \\
\text { in) }\end{array}$ & \\
\hline $\mathrm{Mn}^{2+}$ & $\mathrm{DCP}$ & 0 & 30 & $30 / 0$ & 0 & 30 & $30 / 0$ \\
\hline - & - & $1 \cdot 135$ & $1 \cdot 135$ & 1.00 & 0.430 & 0.435 & 1.01 \\
\hline $5 \times 10^{-6}$ & - & $1 \cdot 140$ & $1 \cdot 110$ & 0.97 & 0.420 & 0.410 & 0.98 \\
\hline $5 \times 10^{-5}$ & - & $1 \cdot 148$ & 0.830 & 0.72 & 0.425 & 0.330 & 0.78 \\
\hline- & $9 \times 10^{-5}$ & $1 \cdot 152$ & $1 \cdot 150$ & 1.00 & 0.430 & 0.420 & 0.98 \\
\hline $5 \times 10^{-6}$ & $9 \times 10^{-5}$ & $1 \cdot 145$ & $1 \cdot 110$ & 0.97 & 0.412 & 0.415 & 1.00 \\
\hline
\end{tabular}

* Absorbance of reaction mixture at $320 \mathrm{~nm}$ after addition of $\mathrm{NaOH}$.

$\dagger$ Absorbance at $380 \mathrm{~nm}$ of 2,4-dinitrophenylhydrazones in $\mathrm{Na}_{2} \mathrm{CO}_{3}$ solution.

by a decrease in absorbance at $320 \mathrm{~nm}$ and was accompanied by an increase at $250 \mathrm{~nm}$, as in the case of oxidation with enzyme. Also, as in enzymatic oxidation, the product of the nonenzymatic destruction failed to react with DNPH.

A kinetic study of phenylpyruvate oxidation was not made because activity was not linear with the amount of enzyme added to the reaction mixture. The nonlinearity varied with different enzyme preparations and incubation conditions. With pyrogallol as the substrate, however, activity was linear with enzyme concentration and incubation time; thus, the enzyme could be quantitatively assayed.

To investigate the possible occurrence of multiple forms of peroxidase, sweetclover homogenates were fractionated on columns of DEAE-cellulose, and the resulting fractions were assayed for activity with both phenylpyruvate and pyrogallol as substrates. A $\mathrm{NaCl}$ gradient was used for elution. Based on assay with pyrogallol, two peaks of peroxidase activity were apparent in the column effluent (Fig. 2a). Both peaks were active in oxidizing phenylpyruvate. In experiments employing ammonium sulfate precipitation prior to fractionation with DEAE-cellulose, both peaks precipitated at $65-80 \%$ ammonium sulfate saturation.

The fractions beyond peroxidase peak II appeared to react with phenylpyruvate but not with pyrogallol (Fig. 2a). A possible explanation is the presence of a separate protein capable of oxidizing only phenylpyruvate. When the $50-65 \%$ ammonium sulfate precipitate, which displayed little activity against pyrogallol, was fractionated on a DEAE-cellulose column, a separate phenylpyruvate oxidase peak (peak III) was plainly evident (Fig. 2 b). The peak III activity differed from the activities in peaks I and II by its inability to react with pyrogallol (or, as shown in other tests, with guaiacol) and by its failure to oxidize phenylpyruvate in the presence of the natural cofactor. Additional experiments indicated that the product of the peak III-catalyzed oxidation of phenylpyruvate, like that from phenylpyruvate oxidations catalyzed by peaks I and II, failed to react with DNPH.

The effects of two independent allelic pairs, $C u / c u$ and $B / b$, on $o$-HCA metabolism in sweetclover have been described. ${ }^{6} \mathrm{CuCu}$ plants are high in content of the glucosides of 


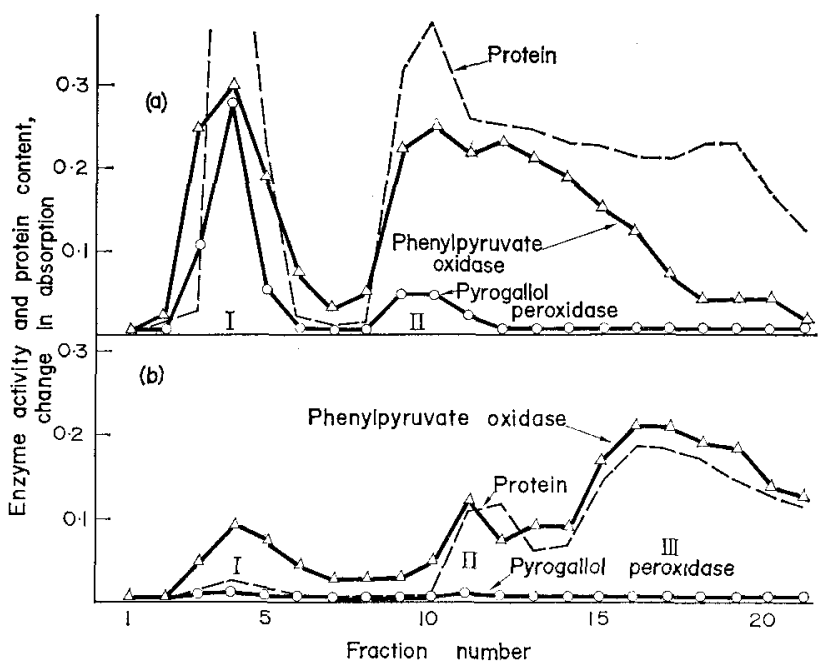

Fig. 2 (a). Peroxidase AND phenylpyruvate oxidase activity IN fRactions from DEAECellulose Chromatography of a hOMOgenate from sWeEtclover. (b) PERoxidase AND PHENYLPYRUVATE OXIDASE ACTIVITY IN FRACTIONS FROM DEAE-CELLULOSE COLUMN CHROMATOGRAPHY OF THE 50-65\% AMMONIUM SULFATE PRECIPITATE OF A SWEETCLOVER HOMOGENATE. Enzyme activity using phenylpyruvate as substrate (measured by $\mathrm{NaOH}$ assay) was determined as given in Experimental except a $0.025-\mathrm{ml}$ sample of each fraction was used. Activity is the loss in absorbance at $320 \mathrm{~nm}$. Enzyme activity using pyrogallol as substrate was measured with the assay given in Experimental except $0.05 \mathrm{ml}$ of each fraction was used. Protein was measured in $0.4 \mathrm{ml}$ of each fraction using $2 \mathrm{ml}$ of Lowry reagent and recording absorbance at $500 \mathrm{~nm}$.

cis- and trans-o-HCA in comparison with cucu plants. Results of isotope feeding experiments indicate that the $\mathrm{Cu} / \mathrm{cu}$ alleles are concerned with the $o$-hydroxylation of cinnamic acid. ${ }^{2} B B$ plants contain a $\beta$-glucosidase which, under suitable conditions, is highly active in hydrolyzing the glucoside of $c i s-a-H C A ; b b$ plants contain little, if any, of this enzyme. ${ }^{13}$ Peroxidase activity was measured in DEAE-cellulose-fractionated tissue homogenates from the four homozygous sweetclover lines, $C u C u B B, C u C u b b, c u c u B B$, and $c u c u b b$. Activity in peaks I and II was assayed with pyrogallol as the substrate (Table 3). Differences were not

Table 3. Peroxidase aCtivity in first AND SECOND PEAKS AFTER FRACTIONATION ON DEAE-CELLULOSE OF THE HOMOGENATES FROM FOUR GENOTYPES OF SWEETCLOVER

\begin{tabular}{lcc}
\hline & \multicolumn{2}{c}{ Peroxidase activity* } \\
Genotype & Peak I & Peak II \\
\hline CuCuBB & $1 \cdot 31$ & $0 \cdot 41$ \\
CuCubb & $1 \cdot 30$ & $0 \cdot 51$ \\
cucuBB & 1.59 & $0 \cdot 64$ \\
cucubb & 1.60 & $0 \cdot 70$
\end{tabular}

* Change in O.D. $/ \mathrm{min} / \mathrm{mg}$ of protein added to DEAEcellulose column.

12 F. A. Haskins and T. Kosuge, Genetics 52, 1059 (1965).

${ }^{13}$ F. A. HASKInS and H. J. GoRZ, Genetics 51, 733 (1965). 
sufficient to indicate a large effect of the $C u / c u$ and $B / b$ allelic pairs on level of peroxidase activity. Peak I contained considerably more activity than peak II in all lines, although this relationship varied, depending on the growth conditions of the tissue. Peak III, which specifically oxidized phenylpyruvate, was also present in all genotypes, but previously mentioned problems with reaction kinetics prevented quantitative measurements with this substrate.

\section{DISCUSSION}

Following chromatography of sweetclover homogenates on DEAE-cellulose, the fractions containing peroxidase activity also display phenylpyruvate oxidase activity. The cofactors needed in the phenylpyruvate oxidase reaction resemble those used in the oxidation of IAA by peroxidase. Commercial horseradish peroxidase can replace the sweetclover homogenate in the phenylpyruvate oxidase reaction. Taken together, these observations support the conclusion that sweetclover peroxidase can oxidize phenylpyruvate.

Phenylpyruvate also undergoes nonenzymatic oxidation if relatively high concentrations of $\mathrm{Mn}^{2+}$ are present. The product produced in the nonenzymatic reaction has not been distinguished from the one produced by peroxidase. In both cases, the product appears not to react with DNPH. Thus, benzaldehyde, which Conn and Seki ${ }^{8}$ identified as a product of phenylpyruvate oxidation by a preparation of lupine mitochondria, appears not to be formed in the reaction catalyzed by the soluble sweetclover preparations used in the present work. The autoxidation of phenylpyruvate was noted by Taniguchi and Armstrong ${ }^{14}$ who, because of the strong, characteristic odor arising from the reaction, suggested that phenylacetic acid was the product. However, no phenylacetic acid odor was detected in the reaction mixtures used in this study.

In its requirement for $\mathrm{Mn}^{2+}$ and $\mathrm{DCP}$ and its failure to react with the usual peroxidase substrates, pyrogallol and guaiacol, the peak III phenylpyruvate oxidase of sweetclover resembles the specific IAA oxidase found in tobacco roots. ${ }^{15}$ Possibly these specific oxidases are artifacts due to elimination of the heme group during extraction; the hemedeficient apoenzymes may be incapable of reacting with the usual peroxidase substrates. ${ }^{11}$

The absence of large differences in peroxidase activity between $\mathrm{CuCu}$ and $c u c u$ plants, which are high and low, respectively, in $o$-HCA, suggests that peroxidase is not important in the $o$-hydroxylation of cinnamic acid. The biological significance of peroxidase in sweetclover remains unclear. It might be speculated that by destroying phenylpyruvate, peroxidase helps to prevent the accumulation of excessive quantities of phenolic compounds, but there is no direct evidence to support this speculation.

\section{EXPERIMENTAL}

Preparation of homogenates. Homogenates were made from the top $1.5 \mathrm{~cm}$ of field-grown sweetclover shoots. Fresh tissue $(2 \mathrm{~g})$ was ground in a cold mortar with $15 \mathrm{ml}$ of $0.05 \mathrm{M}$ borate buffer, $\mathrm{pH} 8.5$, and a small amount of washed sea sand. The homogenates were centrifuged at $17,000 \mathrm{~g}$ for $10 \mathrm{~min}$ at $0^{\circ}$. The resulting supernatant fractions were added to Sephadex G-25 columns, $2.2 \times 32 \mathrm{~cm}$, which were then washed with $0.01 \mathrm{M}$ borate buffer, $\mathrm{pH} 8.5$. Activity was eluted from the column in the exclusion volume.

Fractionation of homogenates. Enzyme-containing fractions ( $10 \mathrm{ml}$ total) from the Sephadex G-25 column were added to a DEAE-cellulose column, $1 \times 15 \mathrm{~cm}$, packed under atmospheric pressure. The DEAE-cellulose, prepared according to the method of Peterson and Sober, ${ }^{16}$ was eluted by a $\mathrm{NaCl}$ gradient

14 K. Taniguchi and M. D. Armstrong, J. Biol. Chem. 238, 4091 (1963).

15 L. Sequeira and L. Mineo, Plant Physiol. 41, 1200 (1966).

16 E. A. Peterson and H. A. Sober, in Methods in Enzymology (edited by S. P. Colowick and N. O. Kaplan), Vol. 5, p. 3, Academic Press, New York (1964). 
formed by siphoning $150 \mathrm{ml}$ of $0.01 \mathrm{M}$ borate buffer, $\mathrm{pH} 8.5$, containing $1.0 \mathrm{M} \mathrm{NaCl}$, into $150 \mathrm{ml}$ of $0.01 \mathrm{M}$

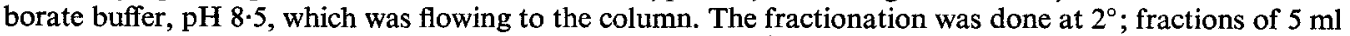
were collected. Protein was measured by the Lowry method. ${ }^{17}$

A homogenate which had been centrifuged but not deionized was used for $\left(\mathrm{NH}_{4}\right)_{2} \mathrm{SO}_{4}$ precipitation. The $50-65 \%$ cut was washed through a Sephadex G-25 column with $0.01 \mathrm{M}$ borate buffer, $\mathrm{pH} 8 \cdot 5$, before fractionation on a DEAE-cellulose column.

Enzyme assay. The reaction mixture (vol. $0.2 \mathrm{ml}$ ) for measuring phenylpyruvate oxidase activity contained the following: $10^{-3} \mathrm{M}$ phenylpyruvate, $9 \times 10^{-5} \mathrm{M} \mathrm{DCP}, 5 \times 10^{-6} \mathrm{M} \mathrm{MnCl}_{2}$, and $3 \times 10^{-2} \mathrm{M}$ borate, pH $8 \cdot 5$. A $0.01-\mathrm{ml}$ sample of the deionized enzyme preparation was used. Incubation time was $30 \mathrm{~min}$; incubation temperature was $30^{\circ}$. In the ' $\mathrm{NaOH}$ ' assay of phenylpyruvate, ${ }^{9}$ the reaction was stopped by adding $2.0 \mathrm{ml}$ of $1 \mathrm{~N} \mathrm{NaOH}$, and absorbance was measured at $320 \mathrm{~nm}$ with a Beckman DB-G recording spectrophotometer.

The 'DNPH' assay was based on the procedure of Bonting ${ }^{18}$ for pyruvic acid. To stop the reaction (same mixture as indicated in the preceding paragraph), $0.4 \mathrm{ml}$ of $0.1 \% \mathrm{DNPH}$ in $4 \mathrm{~N} \mathrm{HCl}$ was mixed with the reaction constituents. After $5 \mathrm{~min}, 2 \mathrm{ml}$ of ethyl ether was added and the mixture was shaken for $15 \mathrm{sec}$. A $1-\mathrm{ml} \mathrm{sample}$ of the ether phase was then shaken with $2 \mathrm{ml}$ of $10 \% \mathrm{Na}_{2} \mathrm{CO}_{3}$ for $15 \mathrm{sec}$, and the ether phase was removed by suction. The absorbance of the carbonate phase was read at $380 \mathrm{~nm}$.

For peroxidase assay, the reaction mixture contained the following in a volume of $1.1 \mathrm{ml}: 1.8 \times 10^{-2} \mathrm{M}^{-1}$ pyrogallol, $1.4 \times 10^{-3} \mathrm{M} \mathrm{H}_{2} \mathrm{O}_{2}$, and $2.3 \times 10^{-2} \mathrm{M}$ borate, $\mathrm{pH} 8.5$. A $0.025-\mathrm{ml}$ sample of the deionized homogenate was used. Incubation time was $1 \mathrm{~min}$, and incubation temperature was $30^{\circ}$. The reaction was stopped by the addition of $1 \mathrm{ml}$ of $5 \mathrm{~N} \mathrm{H}_{2} \mathrm{SO}_{4}$, and absorbance was read at $430 \mathrm{~nm}$. For peroxidase assay of the 4 sweetclover genotypes, activity in each fraction from a DEAE-cellulose column was measured, and activities were added to give totals for peaks I and II of each genotype.

Extraction of natural cofactor. Frozen sweetclover shoots $(1 \mathrm{~g})$, following storage in a freezer for about 1 month, were ground in $7.5 \mathrm{ml} \mathrm{H} \mathrm{H}_{2} \mathrm{O}$, and the homogenate was centrifuged at $17,000 \mathrm{~g}$ for $10 \mathrm{~min}$. The supernatant fluid was boiled for 5 min to destroy enzyme activity, and the preparation was recentrifuged. The resulting supernatant was diluted with an equal volume of $\mathrm{H}_{2} \mathrm{O}$. When the natural activator was used in assays, $0.01 \mathrm{ml}$ of this diluted solution was added to the reaction mixture in place of $\mathrm{Mn}^{2+}$ and DCP.

Materials. Derivation of the four sweetclover genotypes, $C u C u B B, C u C u b b, c u c u B B$, and $c u c u b b$, has been described previously. ${ }^{19}$ Pyrogallol was purchased from Fisher Chemicals and horseradish peroxidase and $\beta$-phenylpyruvic acid from Sigma Chemicals. Horseradish peroxidase was diluted to $0.6 \mathrm{mg} / 50 \mathrm{ml}$ in water to provide a preparation with approximately the same activity per $\mathrm{ml}$ as the sweetclover homogenate. Other chemicals were obtained from usual commercial sources.

17 O. H. Lowry, N. J. Rosebrough, A. L. Farr and R. J. Randall, J. Biol. Chem. 193, 265 (1951).

18 S. L. Bonting, Arch. Biochem. Biophys. 58, 100 (1955).

19 H. J. Gorz and F. A. Haskins, Crop Sci. 9, 79 (1969).

Key Word Index-Melilotus alba; Leguminosae; sweet clover; peroxidase; phenylpyruvate oxidation. 